\title{
RESEARCH
}

Open Access

\section{Litterfall dynamics and soil carbon and nitrogen stocks in the Brazilian palm swamp ecosystems}

\author{
Gracielle de Brito Sales', Taynan Aquilles Marinho Lessa', Daniela Aparecida Freitas', \\ Maria das Dores Magalhães Veloso ${ }^{2}$, Maria Ligia de Souza Silva ${ }^{3}$, Luiz Arnaldo Fernandes ${ }^{1}$ and \\ Leidivan Almeida Frazão ${ }^{1 *}$ (D)
}

\begin{abstract}
Background: This study aimed to determine the litterfall production, accumulation, decomposition rate and nutrient stocks, and to estimate the soil carbon (C) and nitrogen (N) stocks in three palm swamp ecosystems with different land use intensities in the Southeast of Brazil.

Methods: Three palm swamp ecosystems with different land use intensities were evaluated: Agua Doce (AD), conserved area; Capivara (CV), area with small agricultural practices; and Buriti Grosso (BG), area with an intensive land use. Produced and accumulated litterfall from the Cerrado areas surrounding the palm swamps were collected from October 2014 to September 2015, and the Ca, Mg, K, and P concentrations were determined in the dry and rainy seasons. Soil samples were collected in the surrounding Cerrado and within the palm swamps until $100 \mathrm{~cm}$ soil depth to determine bulk density and soil $\mathrm{C}$ and $\mathrm{N}$ contents and stocks.

Results: Annual litterfall production in the Cerrado surrounding palm swamps was similar in AD (3.58

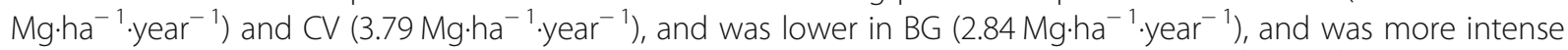

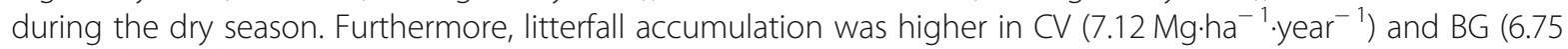
$M g \cdot h a^{-1}$.year ${ }^{-1}$ ), culminating in lower decomposition rates. AD showed the highest decomposition rate (0.60) due to its vegetation structure and conservation. The macronutrient contents from the production and accumulated litterfall had a low influence of the land use, decreasing in the following order: Ca $>K>M g>P$. Soils in CV and BG palm swamp areas showed higher values of $C$ and $N$ contents, due to the use of land for agricultural crops and cattle raising in an extensive (rangeland) system. The BG palm swamp, showed the highest C (124.03 Mg.ha $\left.{ }^{-1}\right)$ and $\mathrm{N}\left(10.54 \mathrm{Mg} \cdot \mathrm{ha}^{-1}\right)$ stocks due to the land use history with different agricultural practices over time.

Conclusions: The litterfall dynamics in the Cerrado surrounding palm swamps was more affected by climatic variables than the intensity of land use, but the litter decomposition was more accelerated in the conserved area. Anthropic interventions with soil organic matter (SOM) inputs contributed to an increase in soil $\mathrm{C}$ and $\mathrm{N}$ stocks in the palm swamp ecosystems.
\end{abstract}

Keywords: Nutrient cycling, Soil fertility, Soil organic matter, Decomposition rate

\footnotetext{
* Correspondence: lafrazao@ica.ufmg.br

'Instituto de Ciências Agrárias, Universidade Federal de Minas Gerais,

Avenida Universitária, 1000, Montes Claros, MG 39404-547, Brazil

Full list of author information is available at the end of the article
}

\section{Springer Open}

(c) The Author(s). 2020 Open Access This article is licensed under a Creative Commons Attribution 4.0 International License, which permits use, sharing, adaptation, distribution and reproduction in any medium or format, as long as you give appropriate credit to the original author(s) and the source, provide a link to the Creative Commons licence, and indicate if changes were made. The images or other third party material in this article are included in the article's Creative Commons licence, unless indicated otherwise in a credit line to the material. If material is not included in the article's Creative Commons licence and your intended use is not permitted by statutory regulation or exceeds the permitted use, you will need to obtain permission directly from the copyright holder. To view a copy of this licence, visit http://creativecommons.org/licenses/by/4.0/. 


\section{Background}

The Cerrado (tropical savanna) is the second largest biome in Brazil in geographical extension, with marked seasonality and high human interference (Sano et al. 2007). Since the 1970s, this biome has passed through expressive changes in plant cover, with different systems of land use and occupation, leading to impacts on the environment and natural resources (Oliveira and Marquis 2002). Currently, this biome is the target in the advance of agrosilvopastoral frontiers, which have not only led to great losses in biodiversity but have compromised all ecosystem services (Scariot et al. 2005).

Palm swamps (riparian wetlands known as Veredas) are one of the phytophysiognomies of the Cerrado biome established in hydromorphic soils that play an important role in the maintenance of water resources. Therefore, these palm swamps have considerable biological, social, and economic importance, and are characterized as efficient ecological corridors and sheltered areas for bird life in the Cerrado (Tubelis 2009). Palm swamps have borne significant impacts on suppression of original vegetation for introduction of agrosilvopastoral activities (Eloy et al. 2015). Consequently, the intensive land use can promote changes in the dynamics of soil organic matter (SOM), which are reflected in soil carbon and nitrogen stocks (Liu et al. 2006).

Sigua et al. (2006) and Sousa (2013) stated that soil organic matter and nutrient dynamics in hydromorphic areas are affected by changes in the environment, arising, above all, from inadequate soil use and management. Thus, it is probable that both in the palm swamps and in other wetlands, modifications in soil properties and in their ecological functions may be caused not only by direct use of these areas, but also by use of the soil in their adjacent areas (Houlahan et al. 2006). Thus, it is important to emphasize that Cerrado vegetation surrounding the palm swamps is seen as an area for protection and maintenance of these ecosystems, mainly in the lowest topographical areas.

In natural ecosystems of palm swamps, most of the organic matter accumulated on the soil surface mainly consists of plant matter coming from the litterfall decomposition process, which is highly relevant to the nutrient cycling (Souza et al. 2019). The decomposition process results in accumulation of soil organic matter (SOM) and release of its nutrients (Sousa Neto et al. 2017), maintaining the soil fertility and ecosystem productivity. Litterfall decomposition may lead to modifications in the areas over time (Martins 2010; Richards et al. 2010). Thus, nutrient cycling through litterfall accumulation constitutes the most significant way to transfer nutrients in forest ecosystems (Golley 1983).

Therefore, the aim of this study was to estimate the litterfall production, accumulation, decomposition rate and nutrient stocks in the Cerrado surrounding palm swamps, and to determine the soil carbon and nitrogen stocks within three palm swamps areas with different land use intensities in the Southeast of Brazil.

We hypothesised that (i) litter decomposition rate and nutrient stocks are greater in the preserved Cerrado surrounding palm swamps, because the litterfall inputs and enviromental conditions are more favorable for the decomposition process; and (ii) soil carbon and nitrogen stocks can be modified by anthropic interventions in the palm swamp ecosystems, since the agricultural activities can increase soil organic matter over time.

\section{Methods}

\section{Study site}

The study areas are located in the municipalities of Bonito de Minas and Januária as part of the Pandeiros River Environmental Protection Area (EPA) in the Southeast of Brazil (Fig. 1). According to the Köppen classification, the climate in the region is hot semi-arid (Bsh), with welldefined dry and rainy seasons (Inmet 2008).

Considering topography as a parameter of classification of palm swamps, as proposed by Ribeiro and Walter (2008), the study areas have a smoothed surface, i.e., there is a slope between the surrounding environment and the lowest part of the palm swamp. The vegetation of the three areas surrounding the palm swamps is classified as Cerrado stricto sensu, i.e., it is characterized by shorter, leaning and winding trees with a thin trunk and irregular and twisted branches and a large number of grasses in the understory. According to the IUSS Working Group WRB (2015), the soils of the lower part of the palm swamps were classified as Histosols and, in the middle and upper edges, as Gleysols. In the Cerrado surrounding palm swamps, the soils were classified as Arenosols for the three areas. The granulometric fractions (sand, silt and clay) were similar among the three types of soil and the mean of clay content was $50 \mathrm{~g} \cdot \mathrm{kg}^{-1}$ for the three evaluated areas.

The study was conducted in three areas of palm swamps at different anthropization stages, which were managed since the 1960s with different land use intensities as described as follows:

i) Agua Doce (AD): preserved palm swamp ecosystem, in spite of sporadic natural fires, above all in the surrounding Cerrado. The palm swamp was characterized with the presence of typical species of these environments, such as Mauritia fleoxuosa and Maurittiela armata, and the formation zones of the hydromorphic soils are well defined. The Cerrado surrounding the palm swamp is also conserved, although it has different strata of vegetation, due to occurrence of sporadic fire. 


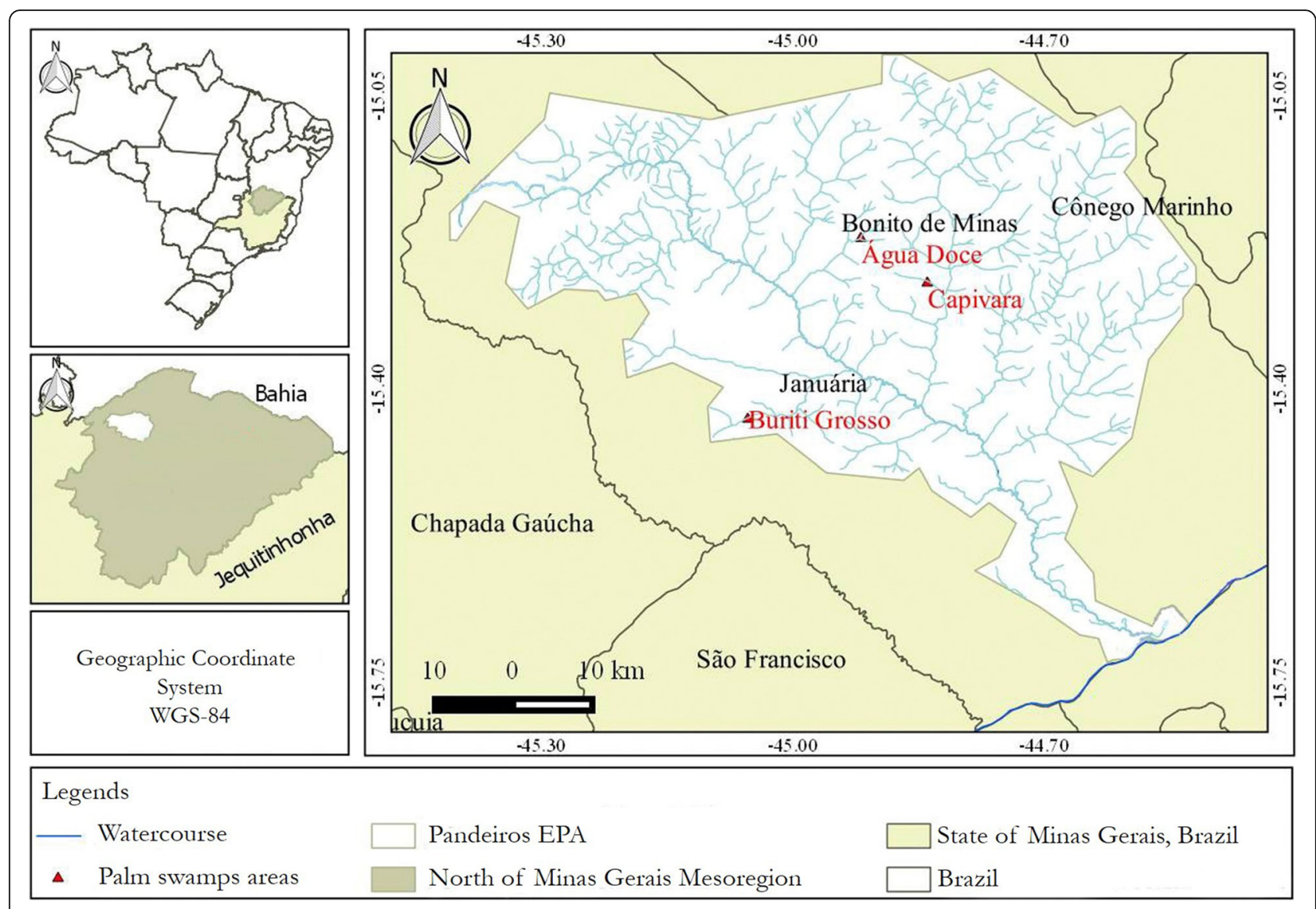

Fig. 1 Location of the study areas in the Southeast of Brazil

ii) Capivara (CV): this palm swamp ecosystem passed through human interventions within and in surrounding areas, which led to silting of the lower parts near the channel of the palm swamp. The anthropic interventions were mainly represented by deforestation of the surrounding Cerrado, by the extensive system of cattle raising, and by burning to establishment of annual crops, which contributed to modification of the natural environment. The soils near the channel of the palm swamp were highly variable across the profile evaluated, due to the silting process.

iii) Buriti Grosso (BG): palm swamp ecosystem located in a Private Nature Reserve (Reserva Particular de Patrimônio Natural - RPPN) since 2006. However, it has a long history of anthropic interventions beginning in the 1960s from large drainage projects for agricultural crops. The practice of subsistence agriculture followed by the rice cultivation in the hydromorphic soils, and planting of eucalyptus in the groundwater recharge areas also contributed to the process of suppression of native vegetation. Annual crops with the use of burning were also predominant for a long period in this area until
2006. There was a high mortality rate of the key species in this palm swamp, such as Mauritia fleoxuosa, as well as transformation of the environment since the hydromorphic soils were transformed to crop production, which reduced the perennial nature of water maintenance throughout the year.

\section{Sampling and data analysis}

Litterfall production, accumulation, decomposition, and nutrient concentrations and stocks were determined in the three areas of Cerrado surrounding AD, CV and BG palm swamps. The soil $\mathrm{C}$ and $\mathrm{N}$ concentrations and stocks and the $\mathrm{C} / \mathrm{N}$ ratio of the soil were determined within palm swamps and in the Cerrado surrounding palm swamps.

The litterfall produced (aerial litter) was collected using collectors placed at a $40-\mathrm{cm}$ height from the soil surface and made of a PVC and 1-mm nylon screen structure with dimensions of $50 \mathrm{~cm} \times 100 \mathrm{~cm}$. In each Cerrado area surrounding the three palm swamps, 10 litter collectors $(n=10)$ were randomly distributed. Collections were made monthly, over the period of a year, from October 2014 to September 2015. The litterfall accumulated on the soil was collected manually, also 
monthly, using PVC guides $(45 \mathrm{~cm} \times 48 \mathrm{~cm})$, which were randomly launched at 10 times $(n=10)$ near the fixed collectors. After collection, the material of litterfall produced or accumulated was stored in bags identified with the number of the collector and the Cerrado area. After that, the samples were taken to the laboratory for sorting and fractions separation.

In the laboratory, the samples were dried in a laboratory oven at $65^{\circ} \mathrm{C}$ until reaching constant weight (approximately $72 \mathrm{~h}$ ). After that, the total dry matter (g) of each sample was determined. The litter decomposition rate was calculated after one year of evaluation by the ratio between the weight of litterfall produced and accumulated, which was estimated by Eq. 1, proposed by Olson (1963):

$$
k=\frac{L}{X s s}
$$

where $k=$ decomposition rate; $L=$ annual litter production $\left(\mathrm{g} \cdot \mathrm{m}^{-2}\right)$; Xss = annual mean of litter accumulation on the soil $\left(\mathrm{g} \cdot \mathrm{m}^{-2}\right)$.

Based on the $k$ values, the mean time (in years and days) necessary for litterfall decomposition $\left(50 \%, t_{0.5} ; 95 \%, t_{0.05}\right)$ was calculated using Eqs. 2 and 3 (Martins 2010):

$$
\begin{aligned}
& t_{0.5}=\frac{\ln 2}{k}=\frac{0.693}{k} \\
& t_{0.05}=\frac{3}{k}
\end{aligned}
$$

Chemical analysis of the macronutrients phosphorus $(\mathrm{P})$, potassium $(\mathrm{K})$, calcium $(\mathrm{Ca})$, and magnesium $(\mathrm{Mg})$ were performed in five composite samples $(n=5)$ obtained from joining the aliquots of the material coming from the leaf fraction of the litterfall produced and accumulated on the soil of each area in reference to October to January (rainy season) and April to July (dry season). These samples were ground in a Wiley mill and then once more dried in a laboratory oven at $50^{\circ} \mathrm{C}$. Chemical analyses of the litter were conducted by nitric perchloric digestion according to the method proposed by Embrapa (1997).

The nutrients were determined using a photocolorimeter and atomic absorption spectrophotometer in the Laboratory of Plant Mineral Nutrition of the Department of Soil Science of the Universidade Federal de Lavras (DCS/UFLA). Estimates of litter nutrient stocks were made based on the method proposed by Vitousek and Sanford Jr (1986), according to Eq. 4:

$$
C_{\mathrm{e}}=t_{\mathrm{e}} \times \frac{T_{\mathrm{s}}}{1000}
$$

where $C_{\mathrm{e}}=$ content of the element $\left(\mathrm{g} \cdot \mathrm{kg}^{-1}\right) ; t_{\mathrm{e}}=$ content of the element in the litterfall $\left(\mathrm{g} \cdot \mathrm{kg}^{-1}\right)$; and $T_{\mathrm{s}}=$ total amount or litterfall fraction $(\mathrm{kg})$.
Soil samples were collected from five sample pits randomly distributed within the palm swamps and in the Cerrado surrounding palm swamps areas at $0-10,10$ $20,20-30,30-50,50-75$, and $75-100 \mathrm{~cm}$ depth layers. In each environment (palm swamps and in the Cerrado surrounding palm swamps), five composite soil samples $(n=5)$ were collected.

Soil samples were air dried and the roots were removed from the samples and then passed through 2$\mathrm{mm}$ sieves. After that, the samples were ground and passed through $0.150-\mathrm{mm}$ sieves to determine soil organic carbon $(\mathrm{C})$ and nitrogen $(\mathrm{N})$ contents in a LECO@CN-2000 analyzer at the Center of Nuclear Energy in Agriculture of the Universidade de São Paulo (CENA/USP).

Soil C and N stocks were calculated $\left(\mathrm{Mg} \cdot \mathrm{ha}^{-1}\right)$, according to Eq. 5 (Veldkamp 1994):

$$
\text { Stock }(\mu)=d \times \mu \times e
$$

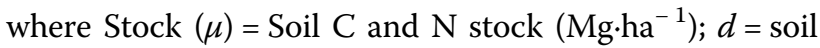
bulk density $\left(\mathrm{g} \cdot \mathrm{cm}^{-3}\right) ; \mu=$ soil $\mathrm{C}$ and $\mathrm{N}$ contents (\%); and $e=$ thickness of the sampled soil layer $(\mathrm{cm})$.

Analysis of variance (ANOVA) was performed to compare all variables analyzed. The means were compared by the Tukey test $(p<0.05)$ with the assistance of the $R$ software, v. 3.2.1.

\section{Results}

The annual litterfall production (ALP) in the Cerrado surrounding $\mathrm{AD}, \mathrm{CV}$, and $\mathrm{BG}$ palm swamps was 3.58 , 3.79, and 2.84 Mg.ha ${ }^{-1} \cdot$ year $^{-1}$, respectively (Fig. 2a). The value obtained in the Cerrado surrounding the BG was significantly lower than those obtained in AD and $\mathrm{CV}$.

The highest values of temporal (seasonal) litterfall production (TLP) was observed in the dry season for the three evaluated study areas, which was double those obtained in the rainy season (Fig. 2b).

The mean values of annual litterfall accumulation (ALA) were $5.88 \mathrm{Mg} \cdot \mathrm{ha}^{-1} \cdot \mathrm{year}^{-1}$ in the Cerrado surrounding the $\mathrm{AD}, 7.12 \mathrm{Mg} \cdot \mathrm{ha}^{-1} \cdot \mathrm{year}^{-1}$ in the $\mathrm{CV}$, and $6.75 \mathrm{Mg} \cdot \mathrm{ha}^{-1} \cdot$ year $^{-1}$ in the BG (Fig. 3a). The values in the Cerrado surrounding the $\mathrm{AD}$ was significantly lower than the results observed in $\mathrm{CV}$ and $\mathrm{BG}$, showing that environmental conditions and the diversity of litter composition in the preserved ecosystem is more favorable for the decomposition process.

The temporal litterfall accumulation (TLA) showed significant variations between the dry and the rainy season (Fig. 3b).

The litterfall decomposition rates $(k)$ in the Cerrado surrounding $A D, C V$, and $B G$ palm swamps were 0.60 , 0.53 , and 0.41 , respectively (Table 1 ). The mean time 


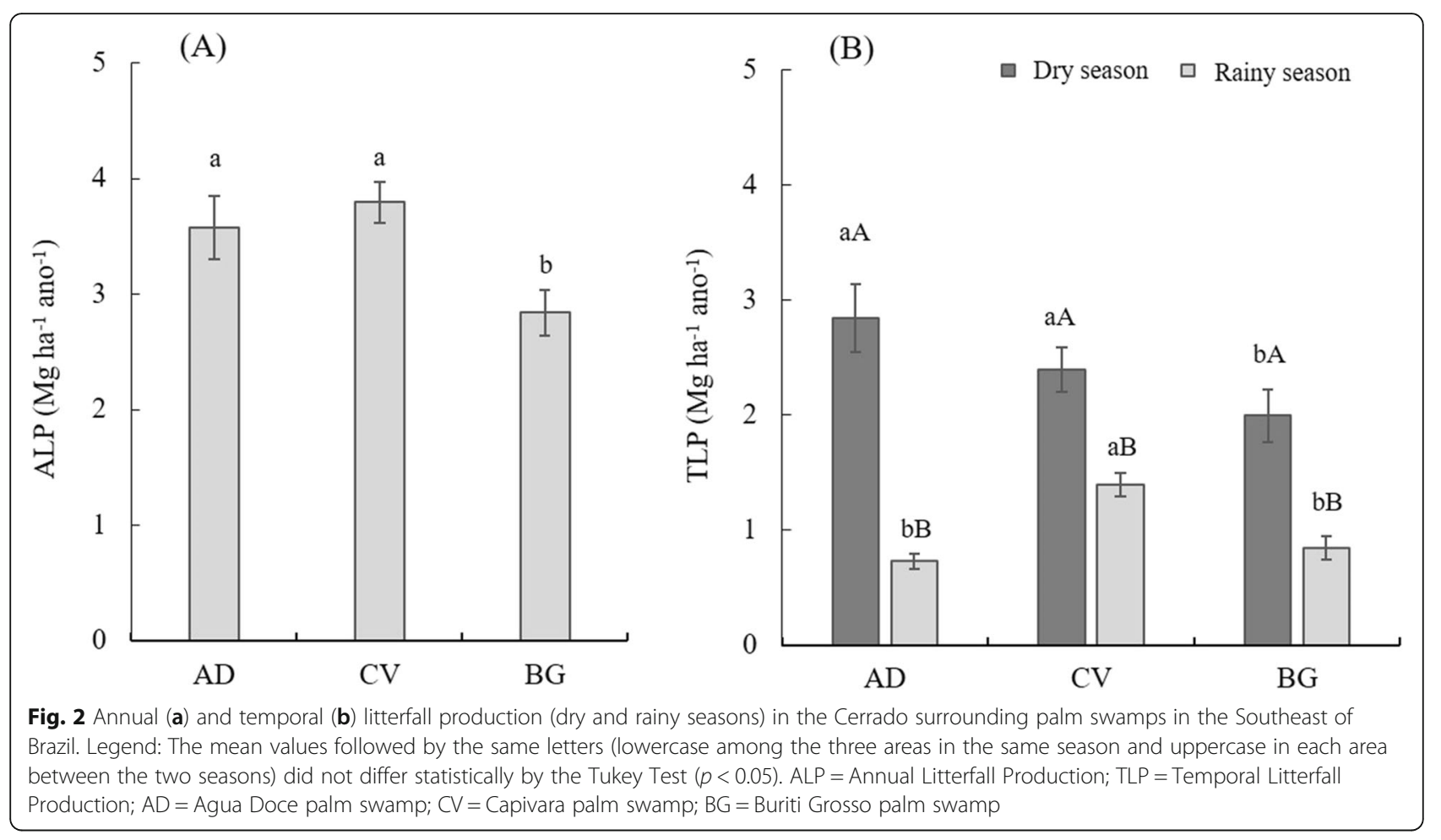

required to reach $50 \%$ and $95 \%$ of decomposition in the three areas increased in accordance with the degree of anthropization, once the time necessary to decompose 95\% of the litter in the Cerrado surrounding BG palm swamp is 2625 days.
The macronutrient contents in the litterfall produced and accumulated varied between the two seasons, and hardly reflected differences according to the history of land use in the three evaluated areas. The concentrations of each nutrient decreased in the following order: $\mathrm{Ca}>\mathrm{K}>\mathrm{Mg}>\mathrm{P}$.

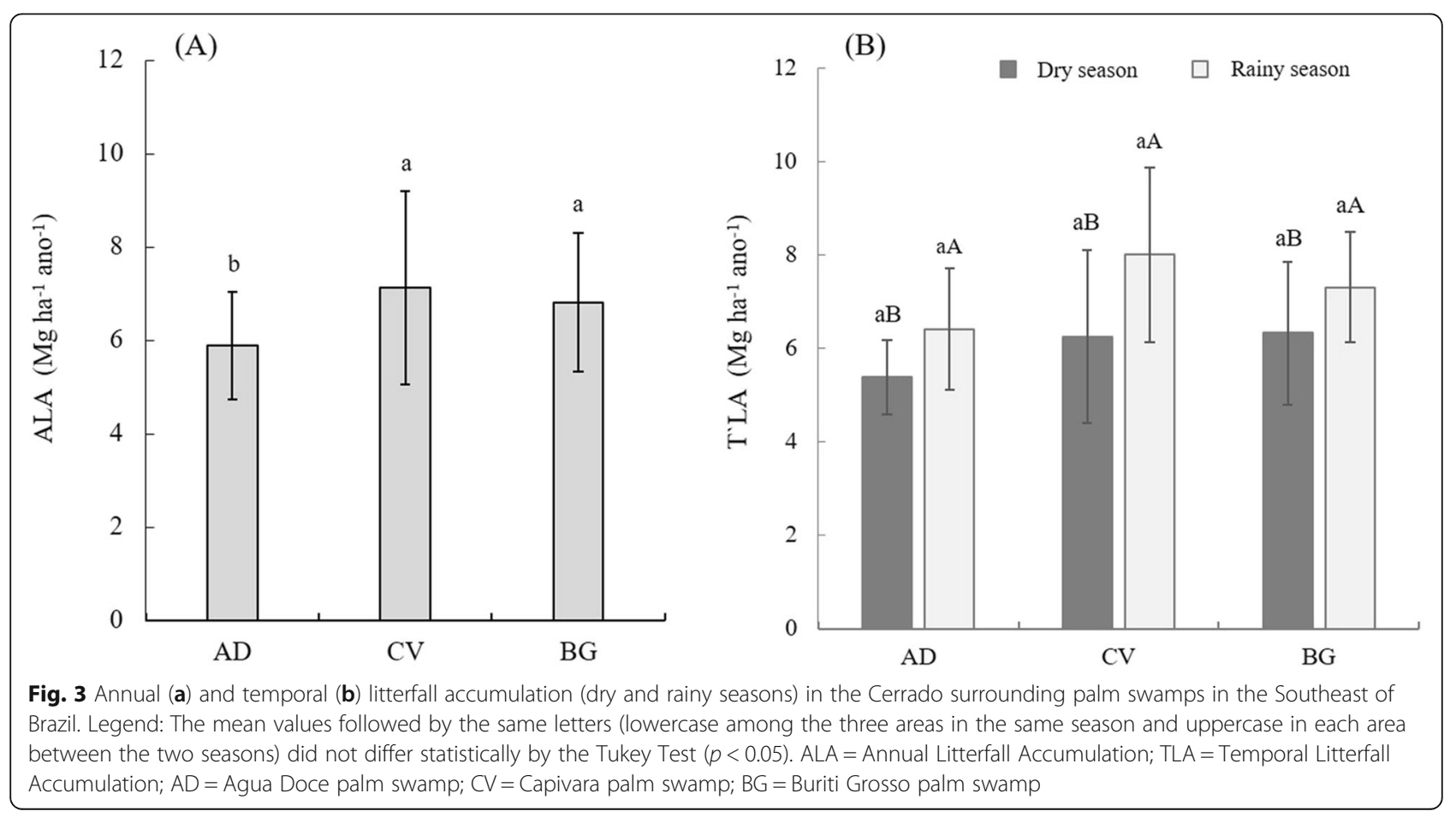


Table 1 Litterfall decomposition rates ( $k$ ) corresponding to 50\% $\left(t_{0.5}\right)$ and $95 \%\left(t_{0.05}\right)$ in the Cerrado surrounding palm swamps in the Southeast of Brazil

\begin{tabular}{llll}
\hline Cerrado area & Decomposition rate $(k)$ & $t_{0.5}$ & $t_{0.05}$ \\
\hline AD & 0.60 & 1.17 (427 days) & 5.06 (1850 days) \\
CV & 0.53 & 1.29 (472 days) & 5.60 (2045 days) \\
BG & 0.41 & 1.66 (606 days) & 7.19 (2625 days) \\
\hline
\end{tabular}

$\mathrm{AD}=$ Agua Doce palm swamp; $\mathrm{CV}$ = Capivara palm swamp; $\mathrm{BG}=$ Buriti Grosso palm swamp; $t_{0.5}$ and $t_{0.05}=$ time necessary to decompose $50 \%$ and $95 \%$ of the litter, respectively

The $\mathrm{P}$ contents in the produced and accumulated litterfall increased in the rainy season compared to the dry season in all evaluated areas (Fig. 4a and b). In the rainy season, the $\mathrm{P}$ contents in the litterfall produced were higher in the Cerrado surrounding $\mathrm{CV}$ than in the $\mathrm{AD}$ and BG $(p<0.05)$. In the dry season, the P contents were higher in the Cerrado surrounding $\mathrm{AD}$ and lower in the Cerrado surrounding CV palm swamp (Fig. 4a). In the rainy season, the results did not differ between the evaluated areas $(p<0.05)$.

The $\mathrm{K}$ contents in the litterfall produced were significantly higher in the rainy season $(p<0.05)$ for the three study areas (Fig. 4c). In the rainy season, there was no difference among the evaluated areas, but in the dry season, $\mathrm{K}$ contents were significantly higher in the Cerrado surrounding $\mathrm{AD}$. The values were higher in TLP than in TLA. Both in the rainy and dry seasons, the $\mathrm{K}$ contents were significantly higher $(p<0.05)$ in the Cerrado surrounding $\mathrm{CV}$ and $\mathrm{AD}$, respectively.

The contents of $\mathrm{Ca}$ in the litterfall produced and accumulated were higher both in the dry and rainy seasons for the three ecosystems (Fig. 4e and f). In the dry season, the $\mathrm{Ca}$ contents in the litterfall produced were significantly higher in the Cerrado surrounding $\mathrm{AD}$, whereas in the rainy season, the same pattern was observed in BG (Fig. 4e). For the litterfall accumulated, the mean values of $\mathrm{Ca}$ contents did not differ among the three areas in the two seasons (Fig. 4f).

Mg contents in the litterfall produced differed among the areas only in the rainy season, with highest values in the Cerrado surrounding the CV (Fig. 4g). In the litterfall accumulated, $\mathrm{K}$ contents also differed only in the rainy season, with highest values in AD (Fig. 4h). Differences between the two seasons were found in $\mathrm{CV}$, with highest values in the litterfall produced (rainy season) and accumulated (dry season) (Fig. 4g and h). BG showed the highest values for $\mathrm{Mg}$ contents in the litterfall accumulated in the dry season (Fig. 4h).

The nutrient stocks in the litterfall produced and accumulated were variable according to the intensity of the land use. The nutrient stocks were higher in the ALA than in ALP for all the areas and nutrients evaluated, except for K (Table 2). Thus, as observed for the macronutrient contents, the mean nutrient stocks in the litterfall decreased in the following order: $\mathrm{Ca}>\mathrm{K}>\mathrm{Mg}>$ P.

The P stocks showed few variations between ALP and ALA, with lower stocks in the ALP in the Cerrado surrounding $\mathrm{CV}$ and $\mathrm{BG}$ (Table 2). As observed for the nutrient contents, $\mathrm{K}$ stocks were higher in ALP. Higher K stocks were found in the Cerrado surrounding $A D$ and $\mathrm{CV}$ where higher annual litterfall production was observed (Fig. 2).

The Ca stocks were higher in ALP and ALA in the Cerrado surrounding AD and CV. Similar result was found to Mg stocks in the ALP, while in the ALA the stocks did not differ among the three areas (Table 2).

The results for soil $\mathrm{C}$ and $\mathrm{N}$ contents and the $\mathrm{C} / \mathrm{N}$ ratio showed variations, reflecting the influence of anthropic activities in the palm swamp ecosystems (Table 3). At $0-10 \mathrm{~cm}$ soil depth, $\mathrm{C}$ content ranged from 4.20 to $14.94 \mathrm{~g} \cdot \mathrm{kg}^{-1}$ within the palm swamps and from 3.94 to $9.27 \mathrm{~g} \cdot \mathrm{kg}^{-1}$ in the Cerrado surrounding palm swamps. The highest values of soil $\mathrm{C}$ contents were found in the CV and BG palm swamps, areas with extensively used for pasture and annual crops cultivation.

In the $10-20 \mathrm{~cm}$ layer, the soil $\mathrm{C}$ contents in $\mathrm{CV}$ and BG palm swamps were similar, and from 20 to $100 \mathrm{~cm}$ soil depths, the values were higher in the BG palm swamp, with values ranging from 6.11 to $11.4 \mathrm{~g} \cdot \mathrm{kg}^{-1}$.

The results for soil $\mathrm{N}$ contents were similar to those observed for C contents (Table 3), however, with lower variation among the environments. Within the BG palm swamp, we found the lowest variability of $\mathrm{N}$ contents in soil profile up to $100 \mathrm{~cm}(0.58$ to $\left.0.69 \mathrm{~g} \cdot \mathrm{kg}^{-1}\right)$, possibly due to the history of land use with perennial and annual crops in this area. The lowest $\mathrm{N}$ contents were found within the $\mathrm{AD}$ palm swamp, with values ranging from 0.15 to $0.39 \mathrm{~g} \cdot \mathrm{kg}^{-1}$. The highest values of soil $\mathrm{N}$ contents were observed within the $\mathrm{CV}$ palm swamp, ranging from 0.16 to $0.92 \mathrm{~g} \cdot \mathrm{kg}^{-1}$ in the soil profile evaluated.

The results found for the $\mathrm{C} / \mathrm{N}$ ratio were variable among the study areas, with values ranging from 9.25 to 18.4 (Table 3).

The soil density used for calculation of the soil $\mathrm{C}$ and $\mathrm{N}$ stocks showed no differences among the areas, and the mean values found until $100 \mathrm{~cm}$ depth layer for $\mathrm{AD}, \mathrm{CV}$ and $\mathrm{BG}$ palm swamps were 1.47, 1,45 and $1,43 \mathrm{~g} \cdot \mathrm{cm}^{-3}$, respectively. The soil $\mathrm{C}$ and $\mathrm{N}$ stocks $(0-100 \mathrm{~cm})$ had the same pattern observed in relation to the $\mathrm{C}$ and $\mathrm{N}$ contents, and ranged from 33.37 to 124.03 Mg.ha ${ }^{-1}$ (soil C stocks), and from 3.94 to 10.54 Mg.ha ${ }^{-1}$ (soil N stocks) (Fig. 5). The BG palm swamp showed the highest values for soil $\mathrm{C}$ and $\mathrm{N}$ stocks compared to the other areas. 

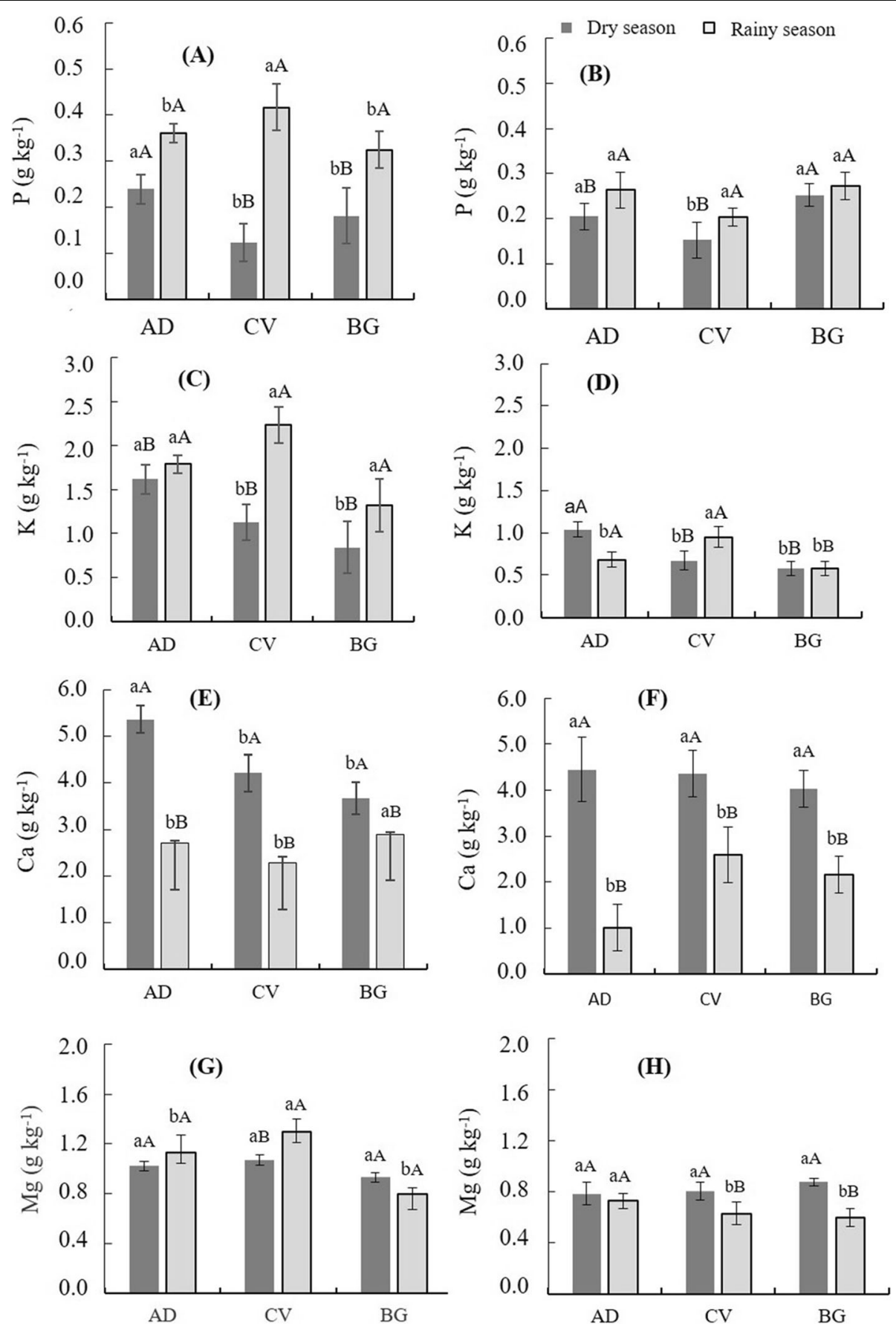

Fig. 4 Levels of $P, K, C a$, and $M g$ in the litterfall produced ( $\mathbf{a}, \mathbf{c}, \mathbf{e}$ and $\mathbf{g}$ ) and accumulated ( $\mathbf{b}, \mathbf{d}, \mathbf{f}$ and $\mathbf{h}$ ) on the soil in the dry and rainy seasons in the Cerrado surrounding palm swamps in the Southeast of Brazil. Legend: The mean values followed by the same letters (lowercase among the three areas in the same season and uppercase in each area between the two seasons) did not differ statistically by the Tukey Test ( $p<0.05)$. $\mathrm{AD}=$ Agua Doce palm swamp; $\mathrm{CV}$ = Capivara palm swamp; BG = Buriti Grosso palm swamp

\section{Discussion}

Our study is the first to analyse litterfall dynamics comparing three areas of Cerrado surrounding palm swamps taking into account the anthropization process. The Cerrado surrounding BG palm swamp ecosystem is an area with a vast history of anthropic interventions. So, the
ALP (Fig. 3a) in this area is directly related to the litterfall deposition over the year, i.e., little deposition of materials such as leaves, stems, branches, fruits, flowers, and other parts of the plant, as well as animal remains (Santos and Válio 2002). As we found in this study (Fig. 3b), several studies have also reported the 
Table 2 Average of soil nutrient stocks in annual litterfall produced (ALP) and accumulated (ALA) in the Cerrado surrounding palm swamps in the Southeast of Brazil

\begin{tabular}{|c|c|c|c|c|c|c|c|c|}
\hline \multirow{2}{*}{$\begin{array}{l}\text { Cerrado } \\
\text { area }\end{array}$} & \multicolumn{2}{|c|}{$P\left(\mathrm{~kg}^{\prime} \cdot \mathrm{ha}^{-1}\right)$} & \multicolumn{2}{|c|}{$\mathrm{K}\left(\mathrm{kg} \cdot \mathrm{ha}^{-1}\right)$} & \multicolumn{2}{|c|}{$\mathrm{Ca}\left(\mathrm{kg} \cdot \mathrm{ha} \mathrm{a}^{-1}\right)$} & \multicolumn{2}{|c|}{$\mathrm{Mg}\left(\mathrm{kg} \cdot \mathrm{ha}^{-1}\right)$} \\
\hline & ALP & ALA & ALP & ALA & ALP & ALA & ALP & ALA \\
\hline$A D$ & $1.38 \mathrm{aA}$ & $1.77 \mathrm{aA}$ & $6.10 \mathrm{aA}$ & $5.06 \mathrm{aB}$ & $24.0 \mathrm{aB}$ & 29.9 aA & $3.86 \mathrm{aA}$ & $4.46 \mathrm{aA}$ \\
\hline$C V$ & $0.96 \mathrm{bB}$ & $1.28 \mathrm{bA}$ & $6.37 \mathrm{aA}$ & $5.76 \mathrm{aB}$ & $28.0 \mathrm{aB}$ & $41.1 \mathrm{aA}$ & $4.89 \mathrm{aA}$ & $5.11 \mathrm{aA}$ \\
\hline$B G$ & $1.32 \mathrm{aB}$ & $2.80 \mathrm{aA}$ & $3.92 \mathrm{bA}$ & $3.03 \mathrm{bB}$ & $12.0 \mathrm{bB}$ & 26.6 bA & $2.45 \mathrm{bB}$ & $5.02 \mathrm{aA}$ \\
\hline
\end{tabular}

maximum litter production in the dry period (Klinge and Rodrigues 1968; Luizão and Schubart 1987; Boinskis 1989; Martins 2010; Brasil et al. 2017; Souza et al. 2019). The leaf deciduousness of the Cerrado species in the dry season constitutes a plant protection mechanism to minimize the effects of water shortage, increases the litter deposition in the months with low rainfall (Souza et al. 2019) and reduces loss of water through evapotranspiration and thereby maintains plant metabolism (Herbohn and Congdon 1993; Franco et al. 2005), We observed that, even considering the distinct anthropization processes of the three ecosystems evaluated, there is a seasonal pattern of litterfall deposition in the Cerrado surrounding the palm swamps.

As mentioned before, the Cerrado area surrounding $\mathrm{AD}$ was characterized as preserved, with the presence of typical species, which produces ecological equilibrium. This condition reflects the ALA stocks in this area (Fig. 3a), favoring the decomposition processes of the plant and animal residues, as well as mineralization process and nutrient cycling (Prescott 2002). According to García-Palacios et al. (2013), the environmental conditions, litter quality, and soil organisms are described as the controllers of decomposition rates, but the variations of

Table 3 Soil of $\mathrm{C}$ and $\mathrm{N}$ contents and $\mathrm{C} / \mathrm{N}$ ratio within Palm swamps and in the Cerrado surrounding palm swamps in the Southeast of Brazil

\begin{tabular}{|c|c|c|c|c|c|c|}
\hline \multirow{2}{*}{$\begin{array}{l}\text { Layer } \\
(\mathrm{cm})\end{array}$} & \multicolumn{2}{|c|}{ Agua Doce (AD) } & \multicolumn{2}{|l|}{ Capivara (CV) } & \multicolumn{2}{|c|}{ Buriti Grosso (BG) } \\
\hline & Palm swamp & $\overline{C e r r a d o}$ & Palm swamp & $\overline{\text { Cerrado }}$ & Palm swamp & Cerrado \\
\hline \multicolumn{7}{|l|}{$\overline{C\left(g \cdot k^{-1}\right)}$} \\
\hline $0-10$ & $4.20 \mathrm{bA}$ & $3.94 \mathrm{bA}$ & $14.94 \mathrm{aA}$ & $9.27 \mathrm{aB}$ & $11.4 \mathrm{aA}$ & $7.24 \mathrm{abB}$ \\
\hline $10-20$ & $2.75 \mathrm{bA}$ & $3.31 \mathrm{bA}$ & $6.16 \mathrm{aA}$ & $3.57 \mathrm{bB}$ & $6.11 \mathrm{aA}$ & $4.36 \mathrm{aB}$ \\
\hline $20-30$ & $2.69 \mathrm{bA}$ & $3.23 \mathrm{aA}$ & $2.04 \mathrm{bB}$ & $3.01 \mathrm{aA}$ & $6.49 \mathrm{aA}$ & 2.49 bB \\
\hline $30-50$ & $2.40 \mathrm{bA}$ & $3.22 \mathrm{aA}$ & $1.61 \mathrm{bB}$ & $2.71 \mathrm{abA}$ & $7.53 \mathrm{aA}$ & 1.72 bB \\
\hline $50-75$ & $1.47 \mathrm{bB}$ & $2.91 \mathrm{aA}$ & $2.15 \mathrm{bA}$ & $1.82 \mathrm{bA}$ & $7.85 \mathrm{aA}$ & 1.94 bB \\
\hline $75-100$ & $1.52 \mathrm{bB}$ & $2.89 \mathrm{aA}$ & $3.08 \mathrm{bA}$ & $3.07 \mathrm{aA}$ & $8.19 \mathrm{aA}$ & $2.05 \mathrm{bB}$ \\
\hline \multicolumn{7}{|l|}{$N\left(\mathrm{~g} \cdot \mathrm{kg}^{-1}\right)$} \\
\hline $0-10$ & $0.39 \mathrm{bA}$ & $0.35 \mathrm{bA}$ & $0.92 \mathrm{aA}$ & $0.60 \mathrm{aB}$ & $0.58 \mathrm{abA}$ & $0.66 \mathrm{aA}$ \\
\hline $10-20$ & $0.84 \mathrm{aA}$ & $0.28 \mathrm{bB}$ & $0.49 \mathrm{bA}$ & $0.33 \mathrm{bB}$ & $0.66 \mathrm{abA}$ & $0.40 \mathrm{aB}$ \\
\hline $20-30$ & $0.28 \mathrm{bB}$ & $0.36 \mathrm{aA}$ & $0.18 \mathrm{bB}$ & $0.25 \mathrm{aA}$ & $0.69 \mathrm{aA}$ & $0.24 \mathrm{aB}$ \\
\hline $30-50$ & $0.25 \mathrm{abA}$ & $0.28 \mathrm{aA}$ & $0.16 \mathrm{bA}$ & $0.18 \mathrm{bA}$ & $0.67 \mathrm{aA}$ & $0.20 \mathrm{bB}$ \\
\hline $50-75$ & $0.15 \mathrm{bB}$ & $0.34 \mathrm{aA}$ & $0.21 \mathrm{bA}$ & $0.14 \mathrm{bB}$ & $0.62 \mathrm{aA}$ & $0.15 \mathrm{bB}$ \\
\hline $75-100$ & $0.18 \mathrm{bB}$ & $0.26 \mathrm{aA}$ & $0.18 \mathrm{bB}$ & $0.23 \mathrm{abA}$ & $0.63 \mathrm{aA}$ & 0.16 bB \\
\hline \multicolumn{7}{|l|}{ C/N Ratio } \\
\hline $0-10$ & $11.0 \mathrm{cB}$ & $13.7 \mathrm{bA}$ & $17.3 \mathrm{aA}$ & $15.8 \mathrm{aB}$ & $14.3 \mathrm{bA}$ & 11.5 bB \\
\hline $10-20$ & $12.8 \mathrm{aA}$ & $11.8 \mathrm{abB}$ & $13.7 \mathrm{aA}$ & $12.4 \mathrm{aA}$ & 9.12 bB & $11.6 \mathrm{bA}$ \\
\hline $20-30$ & $10.75 \mathrm{bA}$ & $10.1 \mathrm{bA}$ & $11.1 \mathrm{bB}$ & $13.8 \mathrm{aA}$ & $12.2 \mathrm{aA}$ & $11.4 \mathrm{bA}$ \\
\hline $30-50$ & $10.1 \mathrm{bA}$ & 10.4 bA & $15.8 \mathrm{aB}$ & $18.2 \mathrm{aA}$ & $12.7 \mathrm{abA}$ & 9.25 bB \\
\hline $50-75$ & $12.8 \mathrm{aA}$ & 11.7 bA & $11.1 \mathrm{bB}$ & $19.8 \mathrm{aA}$ & $13.7 \mathrm{aA}$ & 13.4 bA \\
\hline 75-100 & 10.7 bA & 10.7 bA & $18.4 \mathrm{aA}$ & $10.5 \mathrm{bB}$ & $14.1 \mathrm{abA}$ & $14.2 \mathrm{aA}$ \\
\hline
\end{tabular}

Legend: The mean values followed by the same letters (lowercase among the three Palm swamps or Cerrado areas, and uppercase for the same ecosystem between Palm swamps and Cerrado) did not differ statistically by the Tukey Test $(p<0.05)$ 


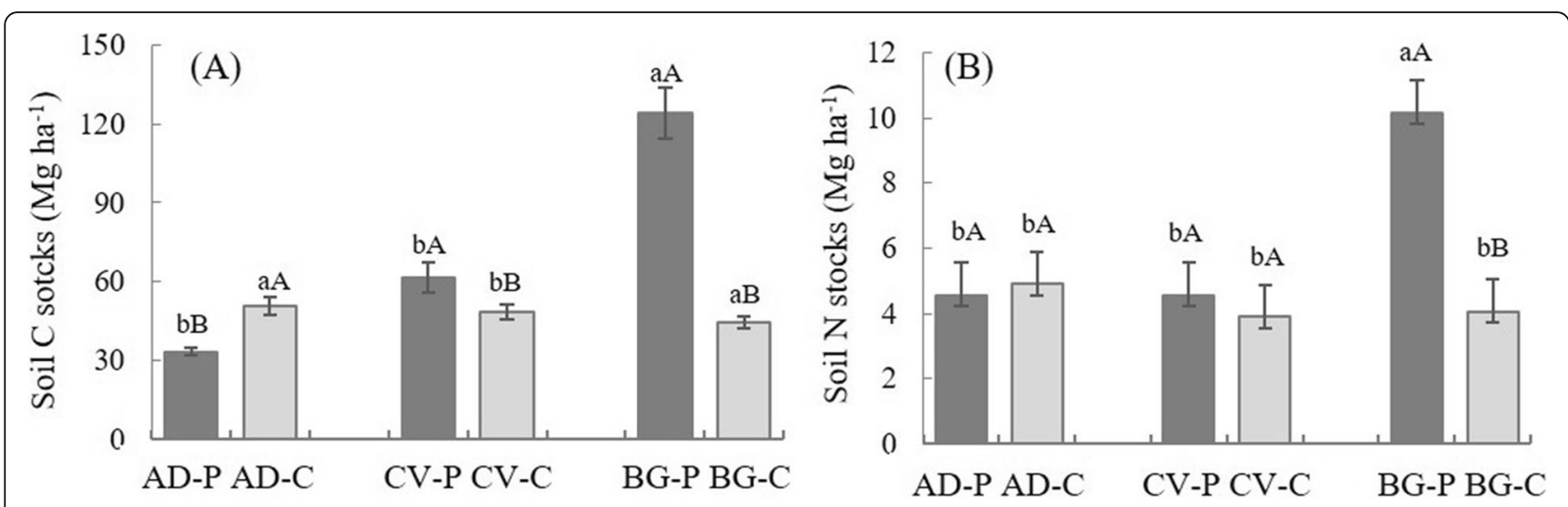

Fig. 5 Soil $C(\mathbf{a})$ and $N(\mathbf{b})$ stocks $\left(M g \cdot h a^{-1}\right.$ ) up to the $100 \mathrm{~cm}$ soil depth within Palm swamps and in the Cerrado surrounding palm swamps in the Southeast of Brazil. Legend: The mean values followed by the same letters ((lowercase among the three Palm swamps or Cerrado areas, and uppercase for the same ecosystem between Palm swamps and Cerrado) did not differ statistically by the Tukey Test $(p<0.05)$. AD-P = Agua Doce (within palm swamp); CV-P = Capivara (within palm swamp); BG-P = Buriti Grosso (within palm swamp); AD-C = Agua Doce (within Cerrado); CV$\mathrm{C}=$ Capivara (within Cerrado); BG-C = Buriti Grosso (within Cerrado)

the litter accumulation in topsoil are also closely related to the seasonality of the litter production (Spain 1975). So, the highest values of TLA (Fig. 3b) were found in the rainy season and the period of greatest plant growth, together with renewal of leaves by species (Brasil et al. 2017). In this period, both the litterfall deposition and the activity of decomposer organisms tend to be higher, but the excessive rainfall in November and December slows the decomposition process due to microorganisms favoring the accumulation of litterfall.

The vegetation of the Cerrado biome may have higher lignin concentrations compared to other phytophysiognomies (Giácomo et al. 2012), and the presence of this compound hinders penetration of decomposer organisms through the cell wall, contributing to the slow decomposition process (Gallardo and Merino 1993). This had a direct influence on the low values of $k(<1.0)$ found in the areas of Cerrado surrounding the palm swamps (Table 1) combined with severe water restriction in the dry season (Olson 1963). Decomposition is primarily the result of microorganism activity (Anderson et al. 1983; Kurzatkowski et al. 2004), although there is a strong influence from climate factors and the quality of the litter (nutrient contents, weight, size of the material, and polyphenol, carbon and nitrogen contents) (Melillo et al. 1982; Taylor et al. 1989; Sousa Neto et al. 2017). Thus, the higher decomposition rate in the Cerrado surrounding $\mathrm{AD}$ may be associated with the proliferation of decomposer microorganisms due to the litter quality and ecological balance provided in this ecosystem.

Contrary to our hypothesis, we found that the macronutrient concentrations in the produced and accumulated litterfall were more influenced by the annual seasons than by the anthropic interventions in the Cerrado areas surrounding palm swamps. The $\mathrm{P}$ contents values (Fig. 4a and b) may be associated with the higher rate of nutrient transfer in the rainy season (Vital et al. 2004), and the contents have declined in the litterfall accumulated because macronutrient is associated with high internal translocation to young plant tissues in formation, declining in plant tissues in processes of senescence (Hawkesford et al. 2012). According to Rossato et al. (2013), these differences can be explained by the floristic composition of the species and by the influence of environmental conditions on the ecosystems evaluated.

Contrary to our observation in this study (Fig. 4c), Vital et al. 2004 found that the K contents tended to decline in the rainy period, because this element is easily washed and leached since it is in the plant tissues in ionic form. Nevertheless, our results can be explained by the topography and location of the studied areas, which are favorable to accumulations from leaching processes. These accumulations are taken up by plant roots and become abundant in the plant tissues and, consequently, in the litterfall produced (Torres and Pereira 2008). The K contents declined in litterfall accumulated (Fig. 4d) and this result can be related to the low rates of this nutrient in biogeochemical cycling (Godinho et al. 2013).

On the other hand, the higher $\mathrm{Ca}$ contents in the litterfall (Fig. 4e and f) can be explained by the low mobility of this element in the plant once it is associated with lignification and the constitution of cell walls, increasing its concentration in the branches and leaves, which are the main components of the litter (Schumacher et al. 2004). Since it is a structural element of plant tissue cells, Ca tends to be one of the last elements to be released to the soil through litter decomposition (Godinho et al. 2014).

According to Luizão and Schubart (1987), Mg as does $\mathrm{P}$ contributes to the biological relations of the soil, and 
it is of great importance for decomposition of soil organic matter. However, as we can found in this study (Fig. $4 \mathrm{~g}$ and $\mathrm{f}$ ), Mg concentration is normally reduced in the leaves, probably due to oxidation of chlorophyll in the process of senescence and when they begin to decompose on the soil (Brun et al. 2001).

Our results about macronutrients stocks (Table 2) were similar to those found by Godinho et al. (2013) and Ribeiro et al. (2017) in areas of a Semideciduous Seasonal Forest and Cerrado senso stricto, respectively. Akhtar et al. (2008) have reported that P stocks is associated with high internal translocation to young plant tissues in formation, and its content declines in tissues in the process of senescence, thus resulting in a high concentration in the litterfall produced. However, the opposite result in this study (Table 2) is explainable because the Cerrado surrounding $\mathrm{CV}$ and BG palm swamps having been subject to high anthropic intervention, which seriously suppressed the native vegetation and, consequently, altered the $\mathrm{P}$ dynamics. The higher $\mathrm{K}$ stocks in ALP (Table 2) may be attributed to its high mobility and retranslocation (Moreira and Fageria 2009), as well as to its considerable tendency to be leached in the rainy season (Kolahchi and Jalali 2007), leading to its loss in the ALA. On the other hand, the higher Ca stocks in ALA is related to the low mobility of this nutrient in plant tissues, resulting from its structuring function in the cell walls (Hawkesford et al. 2012). In addition, Ca contributes to efficient cycling in the environment through the fall and decomposition of senescent plant tissues - the older and more senescent the plant material, the greater the relative $\mathrm{Ca}$ concentration will be (Turner and Lambert 2016).

Our results about soil $\mathrm{C}$ and $\mathrm{N}$ contents have confirmed our hypothesis that anthropic interventions can modify and SOM over time. The higher $C$ contents within the palm swamps (Table 3) are related to the extensive and deep organic layers typical of Histosols, which contribute to an effective soil carbon storage (Bridgham et al. 2006), and the accumulation in the surface layers $(0-10 \mathrm{~cm})$ is due to the constant input of organic matter from the vegetation (Jobbágy and Jackson 2000). The highest values of $C$ contents in $C V$ and $B G$ is related to the roots expansion of the pastures ( $\mathrm{C} 4$ photosynthetic pathway) and the other plants, adding to the $\mathrm{C}$ from plant residues coming from the annual crops in these areas (Franzluebbers and Stuedemann 2008). Additionally, BG palm swamp passed through strong agrossilvopastoral use beginning in the 1960s, with turnover of the soil layers for planting the rice crop in the hydromorphic soils and, after that, eucalyptus and annual crops, modifying the natural environment and the soil characteristics. The supposition is that the increase in $\mathrm{C}$ in depth in this area is related to the management system adopted, to the species that were grown, and to the edaphic and climatic conditions, which favored greater storage of SOM (Aranda and Comino 2014). Consequently, crop systems also added organic matter in depth through root biomass and lead to increases on soil C (Bayer et al. 2000). The burning practice at BG also was used in the past, and pyrogenic $\mathrm{C}$, or $\mathrm{C}$ coming from incomplete combustion, can be significantly degraded on a decade time scale, depending on the material of origin and on the conditions of formation (Bird et al. 1999).

Considering the soil types and the land use intensity in the evaluated areas, both the soil $\mathrm{C}$ and $\mathrm{N}$ contents were low, mainly to Gleysols (Table 3), and this result can be attributed to suppression of native vegetation for agricultural cropping, low diversity of species, and exposure of soil to external factors that contribute to reduction in its quality (Rocha et al. 2014). For the Arenosol, the values of $\mathrm{C}$ and $\mathrm{N}$ found in this study are near those found in studies conducted in the Cerrado by other authors (Frazão et al. 2010; Caetano et al. 2013).

Values of $\mathrm{C} / \mathrm{N}$ ratio lower than 20 (Table 3) were common for the evaluated ecosystems. The decomposition process of plant residues is directly affected by their chemical composition (cellulose, hemicellulose, and lignin) and by their $\mathrm{C} / \mathrm{N}$ ratio (Aita and Giacomini 2003), and lignin concentration (lignin is very common in Cerrado species) and the $\mathrm{C} / \mathrm{N}$ ratio contribute to the lower decomposition process in the soil (Mary et al. 1996).

Our results about soil C and N stocks within BG palm swamps (Fig. 5) can be attributed to the agriculture interventions in this area. The constant inputs of residues in this area, soil tillage, and the input of activated carbon derived of burning process over time contributed to the increase in soil $\mathrm{C}$ and $\mathrm{N}$ to deeper layers. In addition, it can be inferred that there is high capacity for addition of $\mathrm{C}$ by the roots from pasture growth in these environments (Bayer et al. 2000). Thus, the soil $\mathrm{C}$ and $\mathrm{N}$ dynamics can change over time, resulting from greater interaction between the plant and animal components and the soil (Sacramento et al. 2013) and increasing the soil $\mathrm{C}$ and $\mathrm{N}$ stocks.

\section{Conclusions}

This study brought new results about litterfall dynamics and soil $\mathrm{C}$ and $\mathrm{N}$ stocks in palm swamps considering the different levels of anthropic intervention in this important ecosystem of the Brazilian Cerrado. We verify that the decomposition process was more accelerated in the preserved area $(A D)$, but the litterfall dynamics in the Cerrado surrounding palm swamps was more affected by the annual season than the land use intensity.

The macronutrient concentrations decreased in the following order: $\mathrm{Ca}>\mathrm{K}>\mathrm{Mg}>\mathrm{P}$ for both produced and 
accumulated litter. We also observed variations between the seasons and the nutrient stocks were higher in the accumulated litterfall for all the evaluated palm swamp ecosystems.

Confirming our second hypothesis, the soil $\mathrm{C}$ and $\mathrm{N}$ stocks were higher within the palm swamp with greater history of land use intensity (BG), an area that lost the original characteristics of palm swamp but had soil management and human interventions with addition of soil organic matter over time.

\section{Abbreviations}

AD: Água Doce; AD-P: Agua Doce (within palm swamp); AD-C: Agua Doce (Cerrado); BG: Buriti Grosso; ALA: Annual litterfall accumulation; ALP: annual litterfall production; ANOVA: Analysis of variance; BG-C: Buriti Grosso (Cerrado); BG-P: Buriti Grosso (within palm swamp); C: Carbon; Ca: Calcium; CV: Capivara; CV-C: Capivara (Cerrado); CV-P: Capivara (within palm swamp); EPA: Environmental Protection Area; K: Potassium; Mg: Magnesium; N: Nitrogen; P: Phosphorus; SOM: Soil organic matter; TLA: Temporal litterfall accumulation; TLP: temporal litterfall production

\section{Acknowledgements}

We would like to thank the members of the Laboratório de Análise de Solos (UFMG), Laboratório de Nutrição Mineral de Plantas (UFLA) and Laboratório de Biogeoquímica Ambiental (CENA/USP) for their help with laboratory work; and the Instituto Estadual de Florestas (IEF) for all the logistical support during the field work.

\section{Authors' contributions}

Conceived and designed the study: Frazão LA, Sales GB and Veloso MDM Collected data and samples in the field: Sales GB, Lessa AML and Frazão LA and Veloso MDM. Processed samples in the lab: Sales GB, Fernandes LA and Silva MLS. Analyzed the data: Frazão LA, Sales GB, Silva MLS and Veloso MDM. Wrote the paper: Sales GB, Lessa AML, Freitas DA, Veloso MDM, Silvva MLS, Fernandes LA and Frazão LA. All authors read and approved the final manuscript.

\section{Funding}

This work was supported by Coordenação de Aperfeiçoamento de Pessoal de Nível Superior - CAPES (Finance Code 001); Fundação de Amparo à Pesquisa do Estado de Minas Gerais - FAPEMIG (PPM-00133-15). The funding agencies had no role in the design of the study and collection, analysis, and interpretation of data and in writing the manuscript.

\section{Availability of data and materials}

The datasets used and/or analysed during the current study are available from the corresponding author on reasonable request.

\section{Ethics approval and consent to participate}

Not applicable.

\section{Consent for publication}

Not applicable.

\section{Competing interests}

The authors declare that they have no competing interests.

\section{Author details}

'Instituto de Ciências Agrárias, Universidade Federal de Minas Gerais, Avenida Universitária, 1000, Montes Claros, MG 39404-547, Brazil.

${ }^{2}$ Universidade Estadual de Montes Claros, Avenida Professor Rui Braga S/N, Montes Claros, MG 39401-089, Brazil. ${ }^{3}$ Universidade Federal de Lavras, Campus Universitário, CP 3037, Lavras, MG 37299-000, Brazil.
Received: 29 January 2020 Accepted: 5 June 2020

Published online: 23 June 2020

\section{References}

Aita C, Giacomini SJ (2003) Decomposição e liberação de nitrogênio de resíduos culturais de plantas de cobertura de solo solteiras e consorciadas. Rev Bras Cien Solo 27(4):601-612

Akhtar MS, Oki Y, Adachi T (2008) Intraspecific variations of phosphorus absorption and remobilization, $\mathrm{P}$ forms, and their internal buffering in brassica cultivars exposed to a P-stressed environment. J Integr Plant Biol 50(6):703-716

Anderson JM, Proctor J, Vallack HW (1983) Ecological studies in four contrasting lowland rain forest in Gunung Mulu National Park, Sarawak III Decomposition processes and nutrient losses from leaf litter. J Ecol 71(2):503-527

Aranda V, Comino F (2014) Soil organic matter quality in three Mediterranean environments (a first barrier against desertification in Europe). J Soil Sci Plant Nutr 14(3): $743-760$

Bayer C, Mielniczuk J, Amado TJC, Martim Neto L, Fernandes SV (2000) Organic matter storage in a sandy clay loam Acrisol affected by tillage and cropping systems in southern Brazil. Soil Tillage Res 54(1-2):101-109

Bird ML, Moyo C, Veenendaal EM, Lloyd J, Frost P (1999) Stability of elemental carbon in a savanna soil. Glob Biogeochem Cycles 13(4):923-932

Boinskis S (1989) Seasonal patterns in a tropical low land forest. Biotropica 21(33): $223-233$

Brasil JB, Andrade EM, Aquino DN, Júnior LRP (2017) Seasonality in production of leaf litter in two management tropical semiarid. J Env Analy Prog 2(3):167176

Bridgham SD, Megonical JP, Keller JK, Bliss NB, Trettin C (2006) The carbon balance of north American wetlands. Wetlands 26(4): 889-916

Brun EJ, Schumacher MV, Vaccaro S, Spathelf P (2001) Relação entre a produção de serapilheira e variáveis meteorológicas em três fases sucessionais de uma Floresta Estacional Decidual no Rio Grande do Sul. Rev Bras Agromet 9(2): $277-285$

Caetano JO, Benites VM, Silva GP, Silva IR, Assis LR, Cargnelutti Filho A (2013) Dinâmica da matéria orgânica de um Neossolo Quartzarênico de Cerrado convertido para cultivo em sucessão de soja e milheto. Rev Bras Cien Solo 37(5):1245-1255

Eloy L, Aubertin C, Toni F, Lúcio SLB, Bosgiraud M (2015) On the margins of soy farms: traditional population sand selective environmental policies in the Brazilian Cerrado. J Peasant Stud 43(2):494-516

Embrapa-Empresa Brasileira de Pesquisa Agropecuária (1997) Manual de métodos de análise de solo. Centro Nacional de Pesquisa de Solos, Rio de Janeiro, $\mathrm{p}$ 212

Franco AC, Bustamante M, Caldas LS, Goldstein G, Meinzer FC, Kozovits AR, Rundel P, Coradin VTR (2005) Leaf functional traits of Neotropical savanna trees in relation to seasonal water deficit. Trees 19(3):326-335

Franzluebbers AJ, Stuedemann JA (2008) Early response of soil organic fractions to tillage and integrated crop-livestock production. Soil Sci Soc Am J 72(5): $613-625$

Frazão LA, Piccolo MC, Feigl BJ, Cerri CC, Cerri CEP (2010) Inorganic nitrogen, microbial biomass and microbial activity of a sandy Brazilian Cerrado soil under different land uses. Agric Ecosyst Environ 135(3):161-167

Gallardo A, Merino J (1993) Leaf decomposition in two Mediterranean ecosystems of Southeast Spain: influence substrate quality. Ecology 74(1): 152-161

García-Palacios P, Maestre FT, Kattge J, Wall DH (2013) Climate and litter quality differently modulate the effects of soil fauna on litter decomposition across biomes. Ecol Lett 16:1045-1053

Giácomo RG, Pereira MG, Machado DL (2012) Aporte e decomposição de serapilheira em áreas de Cerradão e mata mesofítica na estação ecológica de Pirapitinga -MG. Ci Fl 22(4):669-680

Godinho TO, Caldeira MWW, Caliman JP, Prezotti LC, Watzlawick LF, Azevedo HCA, Rocha JHT (2013) Biomassa, macronutrientes e carbono orgânico na serapilheira depositada em trecho de floresta estacional semidecidual submontana, ES. Sci For 41(97):131-144

Godinho TO, Caldeira MVW, Rocha JHT, Caliman JP, Trazzi PA (2014) Quantificação de biomassa e nutrientes na serapilheira acumulada em trecho de Floresta Estacional Semidecidual Submontana, ES. Cerne 20(1):11-20

Golley FB (1983) Nutrient cycling and nutrient conservation. In: Golley FB (ed) Tropical forest ecosystems: structure and function. Elsevier, Amsterdam, pp $137-156$ 
Hawkesford M, Horst W, Kichey T, Lambers H, Schjoerring J, Moller IS, White P (2012) Functions of macronutrients. In: Marschner P (ed) Marschner's mineral nutrition of higher plants. Elsevier, Oxford, pp 135-189

Herbohn JL, Congdon RA (1993) Ecosystem dynamics at disturbed and undisturbed sites in North Queensland wet tropical rain forest. II - Litterfall. J Trop Ecol 9(3):365-380

Houlahan JE, Keddy PA, Makkay K, Findlay CS (2006) The effects of adjacent land use on wetland species richness and community composition. Wetlands 26(1):79-96

Inmet (2008) Instituto Nacional de Meteorologia. http://www.inmetgovbr Accessed 11 Nov 2018

IUSS Working Group WRB (2015) World Reference Base for Soil Resources 2014, update 2015 International soil classification system for naming soils and creating legends for soil maps. World Soil Resources Reports No. 106. FAO, Rome. http://www.fao.org/soils-portal/soil-survey/soil-classification/worldreference-base/en/. Accessed 12 Nov 2018

Jobbágy EG, Jackson RB (2000) The vertical distribution of soil organic carbon and its relation to climate and vegetation. Ecol Appl 10(2):423-436

Klinge $\mathrm{H}$, Rodrigues WA (1968) Litter production in an area of Amazonian terra firme forest. Part. I: litter-fall, organic carbon and total nitrogen contents of litter. Amazoniana 1(4):287-302

Kolahchi Z, Jalali M (2007) Effect of water quality on the leaching of potassium from sandy soil. J Arid Environ 68(4):624-639

Kurzatkowski D, Martius C, Hofer H, Garcia M, Forster B, Beck L, Vlek P (2004) Litter decomposition, microbial biomass and activity of soil organisms in three agroforestry sites in Central Amazonia. Nutr Cycl Agroecosyst 69(3):257-267

Liu X, Herbert SJ, Hashemi AM, Zhang X, Ding G (2006) Effects of agricultural management on soil organic matter and carbon transformation - a review. Plant Soil Environ 52(12):531-543

Luizão FJ, Schubart H (1987) Litter production and decomposition in a terra-firme forest of Central Amazonia. Experientia 43(3):259-265

Martins SC (2010) Caracterização dos solos e serapilheira ao longo do gradiente altitudinal da Mata Atlântica, Estado de São Paulo. Thesis, Universidade de São Paulo

Mary B, Recous S, Darwis D, Robin D (1996) Interactions between decomposition of plant residues and nitrogen cycling in soil. Plant Soil 181(1):71-82

Melillo JM, Aber JD, Muratore JF (1982) Nitrogen and lignin control of hardwood leaf litter decomposition dynamics. Ecology 63(3):621-626

Moreira A, Fageria NK (2009) Yield, uptake, and retranslocation of nutrients in banana plants cultivated in upland soil of central Amazonian. J Plant Nutr 32(3):443-457

Oliveira PS, Marquis RJ (2002) The Cerrados of Brazil: ecology and natural history of a Neotropical savanna. Columbia University Press, New York, p 401

Olson JS (1963) Energy storage and the balance of producers in ecological systems. Ecology 44(2):322-331

Prescott CE (2002) The influence of the forest canopy on nutrient cycling. Tree Physiol 22(15-16):1193-1200

Ribeiro JF, Walter BMT (2008) As principais fitofisionomias do Bioma Cerrado. In: Sano SM, Almeida SP, Ribeiro JF (eds) Cerrado: ecologia e flora. Embrapa Cerrados, Planaltina, pp 151-212

Ribeiro FP, Bussinguer AP, Hodecker BER, Gatto A (2017) Conteúdo de nutrientes na serapilheira de três fisionomias no Cerrado do Distrito Federal. Pesq Flor Bras 37(92):465-473

Richards AE, Forrester DI, Bauhus J, Lorenzen MS (2010) The influence of mixed tree plantations on the nutrition of individual species: a review. Tree Physiol 30(9):1192-1208

Rocha GP, Fernandes LA, Cabacinha CD, Lopes IDP, Ribeiro JM, Frazão LA Sampaio RA (2014) Caracterização e estoques de carbono de sistemas agroflorestais no Cerrado de Minas Gerais. Cienc Rural 44(7):1197-1203

Rossato DR, Hoffmann WA, Silva LCR, Haridasan M, Sternberg LSL, Franco AC (2013) Seasonal variation in leaf traits between congeneric savanna and forest trees in Central Brazil: implications for forest expansion into savanna. Trees 27(4):1139-1150

Sacramento JAAS, Araújo ACM, Escobar MEO, Xavier FAS, Cavalcante ACR, Oliveira TS (2013) Soil carbono and nitrogen stocks in traditional agricultural and agroforestry systems in the semiarid region of Brazil. Rev Bras Cien Solo 37(3):784-795

Sano EE, Ferreira LG, Asner GP, Steinke ET (2007) Spatial and temporal probabilities of obtaining cloud-free Landsat images over the Brazilian tropical savanna. Int J Rem Sensing 28(12):2739-2752
Santos SL, Válio IFM (2002) Litter accumulation and its effect on seedling recruitment in a southeast Brazilian tropical Forest. Braz J Bot 25(1):89-92

Scariot A, Silva JCS, Felfili JM (2005) Cerrado: Ecologia, Biodiversidade e Conservação. Ministério do Meio Ambiente, Brasília, p 439

Schumacher MV, Brun EJ, Hernandes JI, Konig FG (2004) Produção de serapilheira em uma floresta de Araucariaangustifolia (Bertol.) Kuntze no município de Pinhal Grande-RS. Rev Arvore 28(1):29-37

Sigua GC, Kang WJ, Coleman SW (2006) Soil profile distribution of phosphorus and other nutrients following wetland conversion to beef cattle pasture. J Environ Qual 35(6):2374-2382

Sousa RF (2013) Frações da matéria orgânica e atributos biológicos do solo em Veredas conservadas e antropizadas no bioma Cerrado. Thesis, Universidade Federal de Goiás

Sousa Neto ER, Lins SRM, Martins SC, Piccolo MC, Camargo PB, Carmo JB, Mazzi EA, Houlton BZ, Martinelli L (2017) Litterfall mass and nutrients fluxes over an altitudinal gradient in the coastal Atlantic Forest, Brazil. J Trop Ecol 33(4):261269

Souza SR, Veloso MDM, Espírito-Santo M, Silva JO, Sánchez-Azofeifa A, Souza e Brito BG, Fernandes GW (2019) Litterfall dynamics along a successional gradient in a Brazilian tropical dry forest. For Ecosyst 6:35. doi:https://doi.org/ 10.1186/s40663-019-0194-y

Spain AV (1975) Aspects of the role of the soil biota in forest litter decomposition. Aust For 38(3):171-176

Taylor BR, Parkinson D, Parsons WFJ (1989) Nitrogen and lignin content as predictors of litter decay rates: a microcosm test. Ecology 70(1):97-104

Torres JLR, Pereira MG (2008) Dinâmica do potássio nos resíduos vegetais de plantas de cobertura no cerrado. Rev Bras Cien Solo 32(4):1609-1618

Tubelis DP (2009) Veredas and their use bybirds in the Cerrado, South America: a review. Biota Neot 9(3):363-374

Turner J, Lambert M (2016) Pattern of carbon and nutrient cycling in a small Eucalyptus forest catchment, NSW. Forest Ecol Manag 372:258-268

Veldkamp E (1994) Organic carbon turnover in three tropical soils under pasture after deforestation. Soil Sci Soc Amer J 58(1):175-180

Vital ART, Guerrini IA, Franken WK, Fonseca RCB (2004) Produção de serapilheira e ciclagem de nutrientes de uma floresta estacional semidecidual em zona ripária. Rev Arvore 28(6):793-800

Vitousek PM, Sanford RL Jr (1986) Nutrient cycling in moist tropical forest. Annu Rev Ecol Evol Syst 17(1):137-167

\section{Submit your manuscript to a SpringerOpen ${ }^{\circ}$ journal and benefit from:}

- Convenient online submission

- Rigorous peer review

- Open access: articles freely available online

- High visibility within the field

- Retaining the copyright to your article

Submit your next manuscript at $>$ springeropen.com 